\title{
Perpetuation of Stemphylium blight of garlic under mid hill conditions of Himachal Pradesh
}

\author{
SHABNAM KATOCH and SUMAN KUMAR* \\ Department of Plant Pathology, CSK HP Krishi Vishvavidyalaya, Palampur 176 062, Himachal Pradesh, India
}

Received: 9 May 2017/ Accepted: 10 July 2017/ Published online: 24 July 2017

(C) Indian Phytopathological Society 2017

\begin{abstract}
Blight of garlic caused by Stemphylium vesicarium is of common recurrence and is known to occur in almost all the garlic growing areas of India including Himachal Pradesh. In the present study, surveys during 2014 and 2015 were conducted to assess the pathogen associated and its mode of perpetuation. The morpho-cultural and pathological tests with fungal isolates taken from different areas indicated $S$. vesicarium to be the cause of garlic blight. The pathogen was invariably found to be soil borne in nature and seed borne to some extent. The sexual fruiting bodies (pseudothecia) of Pleospora alli were detected from garlic debris buried at different depths. Inoculation of healthy leaves with pseudothecia produced characteristic leaf spots that highlight the role of plant debris as a source of perpetuation.
\end{abstract}

Keywords: Etiology, garlic, perpetuation, Pseudothecia, Stemphylium vesicarium

Stemphylium blight (Stemphylium vesicarium (Wallr.) Simmons) of garlic (Allium sativum L.) is one of the major constraints for successful cultivation of crop in Himachal Pradesh. The disease was first reported from Kullu valley during 1973 (Singh and Sharma, 1977). High relative humidity and temperature during cropping season favours the leaf blight, further resulting in considerable yield losses. Closer planting, mono-cropping, and susceptibility of local variety led to the explosive development of the disease. The teleomorph of this pathogen, Pleospora alli is reported from various parts of India. In Himachal Pradesh, there are reports on its occurrence (Sugha and Kumar, 2005) and management through chemicals (Devlash, 2011; Khosla et al., 2007). However, current knowledge about the pathogen and its perpetuation with respect to Indian conditions is meagre. Hence, this study was aimed to generate information on etiology of the disease and perpetuation of pathogen so that effective disease management strategy can be developed.

\section{MATERIALS AND METHODS}

\section{Pathogen associated with disease}

Systematic surveys (at 21 locations of HP) were carried out to assess the prevalence of disease from seedling to bulb formation stage during the year 2014 and 2015. The disease severity was recorded by visual observations using 0-9 scale as adopted by Zheng et al. (2010). The associated pathogen was isolated from diseased leaf samples on PDA and further, the pathogenicity was

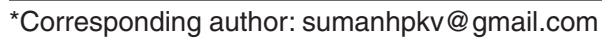

established by inoculating 25 days old plants with spore suspension (Containing 40-50 spores per $10 \mathrm{x}$ microscopic field) of test pathogen. Fungal colony arising from single spore was multiplied on PDA medium and fungi associated was identified by various morphological traits (Symptoms), macroscopic characteristics (colony colour, growth pattern, pigmentation) and microscopic examination (morphology of conidia, size based upon 100 conidia, 25-30 conidiophore length) as a prerequisites for the identification of genera as described by Simmons (1969). Sporulation in cultures was induced by subjecting them to alternate cycles of darkness and light.

\section{Perpetuation of the pathogen}

The role of seed, soil and plant debris in the perpetuation of the pathogen was ascertained as infested soil, seed and diseased crop debris were collected and pot culture experiments were conducted. Each treatment was replicated thrice and the disease incidence or severity was recorded by visual observations using 0-9 scale as adopted by Zheng et al. (2010).

Role of soil: Healthy cloves (3-4/pot) of susceptible cultivar were planted in pots (10 inches in size) filled with 5-6 kg disease-infested soil and sterilized soil, separately. The sets of pots were placed apart from each other under greenhouse conditions and the data on disease severity were recorded at weekly intervals.

Role of seed: The untreated and tebuconazole $(1 \mathrm{~g} / \mathrm{kg})$ treated 3-4 seeds of susceptible variety were sown in pots filled with disease-infested and sterilized soil as follows: Infested soil + apparently healthy seeds, 


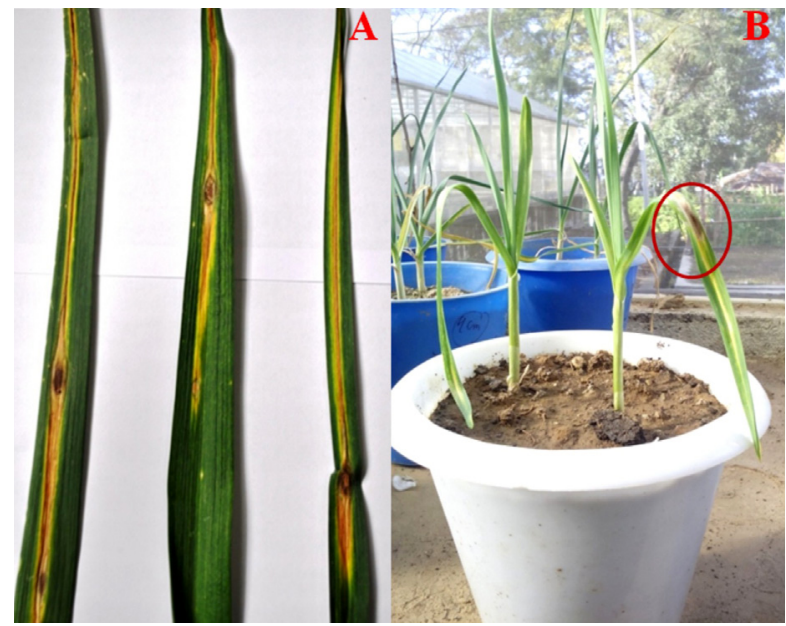

Fig. 1. (A) Symptoms produced by S. vesicarium under natural conditions; (B) Pathogenicity test to confirm the identity of isolated pathogen as the cause of Stemphylium blight

Sterilized soil + apparently healthy seeds, Infested soil + Treated healthy seeds and Sterilized soil + Treated healthy seeds. The data on disease severity were recorded at weekly intervals.

Role of plant debris: Pathogen survival with respect to the presence of anamorph or teleomorph stage was studied by placing plastic nets containing 10 pieces of infested dry garlic leaves at different depths viz., surface, 4,8 and $15 \mathrm{~cm}$ in the field. Debris was sampled at 20 days interval for 5 months and inspected for survival structures. After each sampling, samples of leaf debris were dipped in 0.5 per cent sodium hypochlorite solution for $1 \mathrm{~min}$, which were further immersed in $10 \mathrm{ml}$ of sterile water in Petri dishes and incubated in darkness at $20^{\circ} \mathrm{C}$ for $24 \mathrm{hrs}$ to encourage the release of ascospores (Basallotte-Ureba et al., 1999). The morphological characteristics including color, size and shape of sexual fruiting bodies i.e., pseudothecia, asci and ascospores were recorded. Further, the ascospores suspension was used to inoculate fully established 25 days old (BasalloteUreba et al., 1999) garlic plants and immediately after inoculations, the inoculated plants were transferred to the growth chamber. The data on disease severity were recorded at an interval of 20 days.

\section{RESULTS AND DISCUSSION}

The disease initiated as apical necrosis followed by white small oval lesions which later become sunken with a purple colour surrounded by a whitish margin and ultimately extensive necrosis followed by pre-mature desiccation of the plants (Fig. 1). The disease produced typical symptoms of Stemphylium blight which are in conformity with Basallote-Ureba et al. (1999) who reported that the disease initially appears as small elongated spindle shaped white lesions on leaves, which later become sunken with a purple colour surrounded by a yellowish margin. The pathogen produced cottony, fluffy and dull white mycelial growth along with orange pigmentation when kept at $25^{\circ} \mathrm{C}$. The mature conidia of test pathogen were oblong to oval, dark brown, 32-52 (38.5) $\times 15-26(22) \mu \mathrm{m}$, constricted with 1-4 complete series of longitudinal septa and a variable number of transverse septa. Whereas the conidiophores of test fungus were light brown in colour, swollen at the apex and had conidia which were pointed at the swollen apex of each conidiophore. These results corroborate with the findings of Simmons (1969) who have reported morphological and cultural features of $S$. vesicarium identical to test isolate. The pathogenicity tests on garlic plants using spore suspension of isolated pathogen reproduced typical disease symptoms within 4-5 days of inoculation (Fig. 1) and the findings are in conformity with the results of Basallote-Ureba et al. (1999) who observed that an incubation period of 4-6 days was sufficient for symptom development. Based on the symptomatology, microscopic examinations and pathogenicity tests, the pathogen was identified as $S$. vesicarium, the cause of leaf blight of garlic.

\section{Perpetuation of the pathogen}

Role of soil and seed: Apparently healthy seeds were grown in infested soil resulted in $19.7 \%$ disease severity after one week of disease appearance which increased to $37.0 \%$ after third week. However, apparently healthy seeds grown in sterilized soil gave disease severity of $9.3 \%$ which increased to $14.7 \%$ after third week (Table $1)$. Thus, studies on role of soil and seed revealed the presence of pathogen in the infested soil and seed to some extent. In present investigations, seeds treated with tebuconazole failed to produce any disease and these results are in conformity with the findings of Aveling et al. (1993) who evaluated various seed treatments for the control of Alternaria porri and Stemphylium vesicarium of onion. In onion, S. vesicarium is reported to be seed borne (Ligero et al., 2003) as well as soil borne (Gaikwad et al., 2014) in nature. Thus, the use of an effective treatment could eliminate the potential source of inoculum for disease initiation in field.

Role of plant debris: The information on the role of diseased plant debris buried in soil at different depths (surface, 4,8 and $15 \mathrm{~cm}$ ) in perpetuation of the pathogen and initiation of disease is presented in Table 2. After 20-25 days of burial in soil, only the undifferentiated ascocarps were observed but 3 months later all

Table 1. Role of soil and seed in the perpetuation of $S$. vesicarium infecting garlic

\begin{tabular}{lccc}
\hline Treatments & \multicolumn{3}{c}{ Disease severity (\%) after weeks } \\
\cline { 2 - 4 } & 1 & 2 & 3 \\
\hline Sterilized soil + treated & 0.00 & 0.00 & 0.00 \\
seeds & $(1.00)$ & $(1.00)$ & $(1.0000)$ \\
Infested soil + apparently & 19.67 & 19.67 & 37.00 \\
healthy seeds & $(4.55)$ & $(4.55)$ & $(6.16)$ \\
Sterilized soil + apparently & 9.33 & 12.00 & 14.67 \\
healthy seeds & $(3.21)$ & $(3.59)$ & $(3.958)$ \\
CD $(p=0.05)$ & 0.13 & 0.29 & 0.17 \\
\hline
\end{tabular}

Figures in the parenthesis are square root transformed values 
Table 2. Role of plant debris in the perpetuation of $S$. vesicarium

\begin{tabular}{|c|c|c|c|c|c|}
\hline \multirow[t]{2}{*}{ Depths } & \multicolumn{5}{|c|}{ Disease severity (\%) after 20 days interval } \\
\hline & 20 days & 40 days & 60 days & 80 days & 100 days \\
\hline Surface & $\begin{array}{c}17.8 \\
(4.34)\end{array}$ & $\begin{array}{c}25.7 \\
(5.16)\end{array}$ & $\begin{array}{c}29.5 \\
(5.52)\end{array}$ & $\begin{array}{c}29.3 \\
(4.34)\end{array}$ & $\begin{array}{c}20.3 \\
(5.52)\end{array}$ \\
\hline $4 \mathrm{~cm}$ & $\begin{array}{c}11.8 \\
(3.58)\end{array}$ & $\begin{array}{c}15.5 \\
(4.06)\end{array}$ & $\begin{array}{c}19.8 \\
(4.56)\end{array}$ & $\begin{array}{c}21.3 \\
(3.58)\end{array}$ & $\begin{array}{c}9.67 \\
(4.56)\end{array}$ \\
\hline $8 \mathrm{~cm}$ & $\begin{array}{c}0.00 \\
(1.00)\end{array}$ & $\begin{array}{c}0.00 \\
(1.00)\end{array}$ & $\begin{array}{c}0.00 \\
(1.00)\end{array}$ & $\begin{array}{c}0.00 \\
(1.00)\end{array}$ & $\begin{array}{c}0.00 \\
(1.00)\end{array}$ \\
\hline $15 \mathrm{~cm}$ & $\begin{array}{c}0.00 \\
(1.00)\end{array}$ & $\begin{array}{c}0.00 \\
(1.00)\end{array}$ & $\begin{array}{c}0.00 \\
(1.00)\end{array}$ & $\begin{array}{c}0.00 \\
(1.00)\end{array}$ & $\begin{array}{c}0.00 \\
(1.00)\end{array}$ \\
\hline $\mathrm{CD}(p=0.05)$ & 0.13 & 0.09 & 0.09 & 0.13 & 0.23 \\
\hline
\end{tabular}

Figures in the parenthesis are square root transformed values

pseudothecia become fully mature with asci containing ascospores. The pseudothecia on buried host debris were black, round structures with $125.83 \mu \mathrm{m}$ (average) diameter, asci were bitunicate, club shaped, 80-120 (85.8) $\mu \mathrm{m} \times 12-20$ (16) $\mu \mathrm{m}$ whereas ascospores were light brown, ellipsoid, 16-30 (21) $\mu \mathrm{m} \times 6-13$ (7.5) $\mu \mathrm{m}$ with 4-5 transverse septa and numerous longitudinal septa which concurs with the findings of Basallote-Ureba et al. (1999).

Garlic plants inoculated with ascospores suspension prepared from 20 days old surface placed debris resulted in disease severity of $17.8 \%$ followed by $11.8 \%$ with debris buried at $4 \mathrm{~cm}$ depth. Inoculation with 60 days old surface placed debris resulted maximum disease severity of $29.5 \%$ followed by 29.3 and $20.3 \%$ in 80 and 100 days old debris, respectively. However, $21.3 \%$ disease severity was observed with debris buried at $4 \mathrm{~cm}$ depth at 80 days interval with no disease development at debris buried at 8 and $15 \mathrm{~cm}$ depths. The plant debris, especially near the soil surface seems to play a major role in the perpetuation and initiation of the disease. Thus, the occurrence of pseudothecia on overwintered garlic debris and the development of leaf spots on garlic plants inoculated with ascospores released from pseudothecia revealed its importance as source of inoculum in Stemphylium blight epidemics. These results are in agreement with the findings of Basallote-Ureba et al. (1999), who observed the development of pseudothecia on overwintered garlic leaves affected by leaf spots. Zheng et al. (2010) found that the garlic leaves in the field are one of the most important sources of over summering conidia and mycelia of Stemphylium solani causing garlic leaf blight. These observations are also in conformity with the results reported for asparagus (Evans and Stephens, 1984; Conway, 1987; Falloon et al., 1987; Johnson, 1990).

\section{REFERENCES}

Aveling Theresa AS, Snyman HG and Naude SP (1993). Evaluation of seed treatments for reducing Alternaria porri and Stemphylium vesicarium on onion seed. Plant Dis. 77: 1009-1011.

Basallotte-Ureba MJ, Prados-Ligero AM and Melero-Vara JM (1999). Aetiology of leaf spot of garlic and onion caused by Stemphylium vesicarium in Spain. Plant Pathol. 48: 139145.

Conway KE (1987). Purple spot (Pleospora herbarum) of asparagus in Oklahoma. Plant Dis. 71: 376.

Devlash R (2011). Management of Stemphylium blight of garlic through fungicides. Indian J. Plant Prot. 39: 157-159.

Evans TA and Stephens CT (1984). First report in Michigan of the teleomorph of Stemphylium vesicarium, causal agent of purple spot of asparagus. Plant Dis. 68: 1099.

Falloon PG, Falloon LM and Grogan RG (1987). Etiology and epidemiology of Stemphylium leaf spot and purple spot of asparagus in California. Phytopathology 77: 407-413.

Gaikwad KN, Jadhav SU and Kakulte VR (2014). Management of fungal diseases of onion (Allium cepa L.) by using plant extract. Int. J. Life Sci. Pharma Res. 4: 28-30.

Johnson DA (1990). Effect of crop debris management on severity of Stemphylium purple spot of asparagus. Plant Dis. 74:413.

Khosla K, Thakur BS and Bhardwaj SS (2007). Chemical Management of Stemphylium blight of garlic. Plant Dis. Res. 22: 47-51.

Ligero AMP, Vara JMM, Hervias CC and Ureba MJU (2003). Relationships between weather variables, airborne spore concentrations and severity of leaf blight of garlic caused by Stemphylium vesicarium in Spain. Eur. J. Agron. 109: 301-310.

Simmons EG (1969). Perfect states of Stemphylium. Mycology 61: 1-26.

Singh BM and Sharma YR (1977). Occurrence of leaf blight of garlic caused by Stemphylium botryosum in India. Indian. Phytopath. 30: 272-273.

Sugha SK and Kumar S (2005). Outbreak of Stemphylium blight of Garlic in Himachal Pradesh. Plant Dis. Res. 20: 190191.

Zheng L, Rujing LV, Huang J, Jiang D, Xuhong LIU and Hsiang T (2010). Integrated control of garlic leaf blight caused by Stemphylium solani in China. Can. J. Plant Pathol. 32: 135145. 